\title{
凹部アスペクト比の違いが透過性および不透過性の 側岸凹部流れに与える影響
}

Effects of Aspect Ratio of Side Cavity on Open-Channel Flow with Permeable and Impermeable Side Cavities

\author{
田中貴幸* ·大本照憲** \\ Takayuki TANAKA and Terunori OHMOTO
}

*工博 豊田工業高等専門学校講師 環境システム工学科（テ471-8525 愛知県豊田市栄生町 2 丁目） ** 工博 熊本大学教授 大学院自然科学研究科（干860-8555 熊本市中央区黒髪 2 丁目）

\begin{abstract}
The cavity zone along riverside is expected to produce native habitats of various ecosystems and water-friendly environment. However, effects of side cavities on flow resistance and turbulent flow structures are ambiguous. In this paper, Effects of aspect ratio of side cavity on open-channel flow with permeable and impermeable side cavities were examined experimentally. Velocity fluctuations were measured by using a particle-image-velocimetry (PIV). We revealed the flow resistance could be explained by the difference of mass exchange and momentum transport through the interaction between the side cavity and main flow region.
\end{abstract}

Key Words: cavity flow, turbulent flow structure, momentum transport, PIV

\section{1. はじめに}

河道内における植生やわんどは，多様な生物の生息環境 や親水性の高い水辺環境を形成する上で重要な役割を担 っている. しかしながら, 植生やわんどの存在により河川 の流れが複雑化し, 流れの抵抗が変化するといった治水面 への影響が懸念される. その中で，実河川において植生は 流下方向に連なって群落を形成している様子がみられる が, 河川の多様性や生態系の連続性, 植生群落内が死水域 となることによる水質悪化の懸念など, 諸問題を考慮する と主流部と流れの交換が促進されるような領域を設ける ことが望ましい. このような背景を受け, 植生や側岸凹部 を有する流れの抵抗特性や流動機構については様々な研 究がなされている.

植生群落を有する流れの抵抗特性や流動機構に関する 研究として, 柔軟な植生の密度を変化させた Carollo ら 1), Järvelä ${ }^{2)}$ の研究や, 植生群落の配置を変化させた富 永ら ${ }^{3)}$, 中矢・池田ら ${ }^{4)}$ の研究などが挙げられる. その 中で, 関根ら ${ }^{5)}$ は植生群落を低水路河岸に左右交互に配置 することで, 流下方向に不連続な植生配置における流動機 構と河床変動に関して検討を行っている. 著者ら ${ }^{6)}$ は流下 方向に不連続な植生群落を有する流れについて, 形成され た凹部のアスペクト比を変化させたときの流れの抵抗特 性と流動機構について検討した.

また, 側岸凹部を有する流れの流動機構に関する研究と
しては, 単独の凹部流れにおいて凹部のアスペクト比を変 化させたときの流動機構に関する禰津ら ${ }^{7)}$, 藤田ら ${ }^{8)}$ の研 究が挙げられる. その中で, Uijttewaal ら ${ }^{99}$ は連続的な わんどを有する流れにおいて凹部アスペクト比が異 なる条件における流動機構について検討している. 著者ら ${ }^{10)}$ は流下方向に連続的側岸凹部を有する流 れにおいて，凹部アスペクト比の違いが流れの抵抗 特性および流動機構に与える影響について検討した。 さらに禰津ら ${ }^{11)}$ は, 浸透流を導入した凹部周辺での流れの 特性および物質交換特性に関する可視化実験を行ってい る.

このように, 植生群落のように透過する凹部流れや周囲 が固体壁で囲まれた不透過の口部流れに関して, 流れの抵 抗特性や流動機構について様々な研究がなされている.し かしながらこれらは別々に論じられており, 透過性と不透 過性の違いが流れの抵抗特性や流動機構にどのような影 響を与えるかについて検討している研究はあまり見られ ない.

そのため著者ら ${ }^{12)}$ は, 流下方向に連続的透過性及び不透 過性の側岸口部を有する流れについて, 凹部のアスペクト 比を変化させたときの抵抗特性について検討するととも に, 流れの抵抗が同程度となった 1 つ吅部アスペクト比 に関して平均流特性や凹部周辺の動圧力分布に関して検 討した. しかしながら, 凹部アスペクト比を変化させたと きの連続的透過性および不透過性の側岸凹部流れにおけ る流動機構については検討がなされていない. 


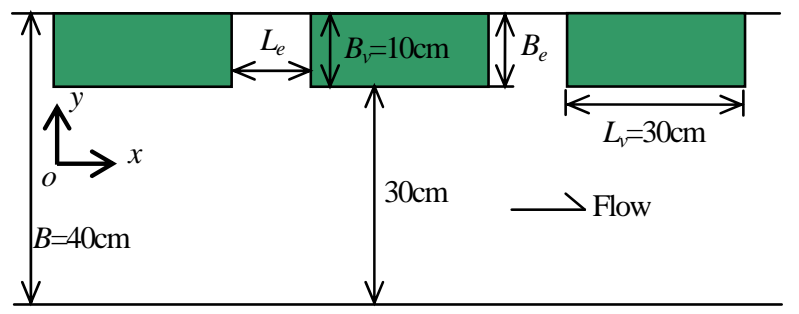

図-1 実験水路概要

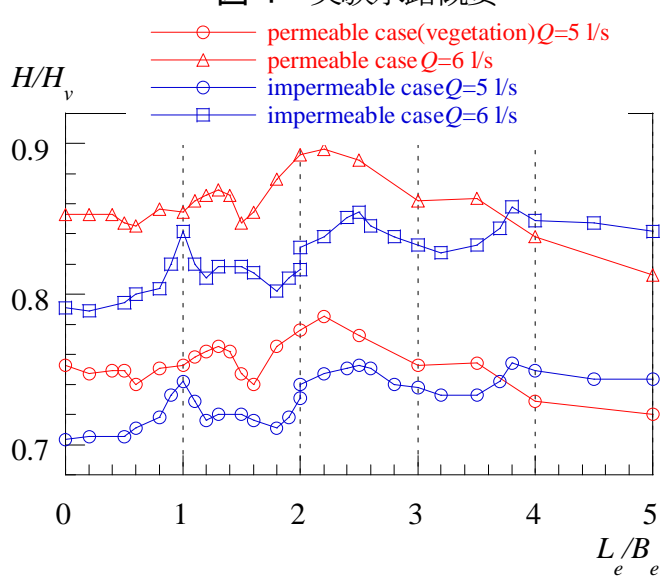

図-2 凹部のアスペクト比と水深の関係 ${ }^{12}$

そこで本研究では流下方向に連続的に透過性および不 透過性の側岸凹部を有する流れにおいて, 凹部アスペクト 比の違いが平均流特性や運動量輸送特性といった流動機 構に与える影響について検討する.

\section{2. 実験装置および実験方法}

実験は全長 $10 \mathrm{~m}$ ，幅 $B=40 \mathrm{~cm}$ ，高さ $20 \mathrm{~cm}$ のアクリル 樹脂からなる循環式可変勾配水路を用いて行った. 植生 帯の模型にはプラスチック板に水流に追随して撓む 6.10 ナイロンブリュウスル（直径 $0.242 \mathrm{~mm}$, 曲げ剛性 $\left.E I=1.45 \times 10^{4} \mathrm{~g} \cdot \mathrm{cm}^{2}\right)$ を $H_{v}=5.5 \mathrm{~cm}$ の高さに揃え, $0.5 \mathrm{~cm}$ 間 隔で貼り付けたものを使用した. 不透過性の側岸凹部流 れに関しては, 水路左岸側にステンレス板によって遮断 物を設置して側岸凹部を形成した. 植生帯および遮断物 の幅は $B_{v}=10 \mathrm{~cm}$ とし, 植生帯および庶断物の流下方向長 さは $L_{v}=30 \mathrm{~cm}$ に設定した. 図-1 のように凹部の流下方向 長さを $L_{e}$, 凹部幅を $B_{e}$ とし, 流れの抵抗特性の計測の際 にはこの凹部の流下方向長さと植生帯幅の比を $L_{e}$ $B_{e}=0 \sim 5.0$ と流量一定という条件の下で変化させた. 本実 験ではマクロ的視点において流れの平衡状態を形成する ため, 流下方向に植生帯および遮断物と口部を交互に水路 上流端より $100 \mathrm{~cm} ９ 40 \mathrm{~cm}$ の位置まで設置している. こ のとき，凹部の流下方向長さを長くしていくと，水路全体 における植生および遮断物の割合は減少していく. 座標系 は植生帯および遮断物上流先端における水路中央の底面 を原点とし，流下方向に $x$ 軸，横断方向に $y$ 軸，鉛直方向 に $z$ 軸をとり右手系とする．また，それぞれの流速成分を $u, v, w$, 平均值を $U, V, W$, 変動成分を $u^{\prime}, v^{\prime}, w^{\prime}$ '表
表-1 実験条件（抵抗特性）

\begin{tabular}{lc}
\hline Cavity width $B_{e}(\mathrm{~cm})$ & 10 \\
Ratio of cavity length and cavity width $L_{e} / B_{e}$ & $0 \sim 5.0$ \\
Vegetation and blocker width $B_{v}(\mathrm{~cm})$ & 10 \\
Vegetation and blocker length $L_{v}(\mathrm{~cm})$ & 30 \\
Vegetation and blocker height $H_{v}(\mathrm{~cm})$ & 5.5 \\
Flow discharge $Q(1 / \mathrm{s})$ & 5,6 \\
Bed slope $I$ & $1 / 500$
\end{tabular}

表-2 実験条件（流動機構）

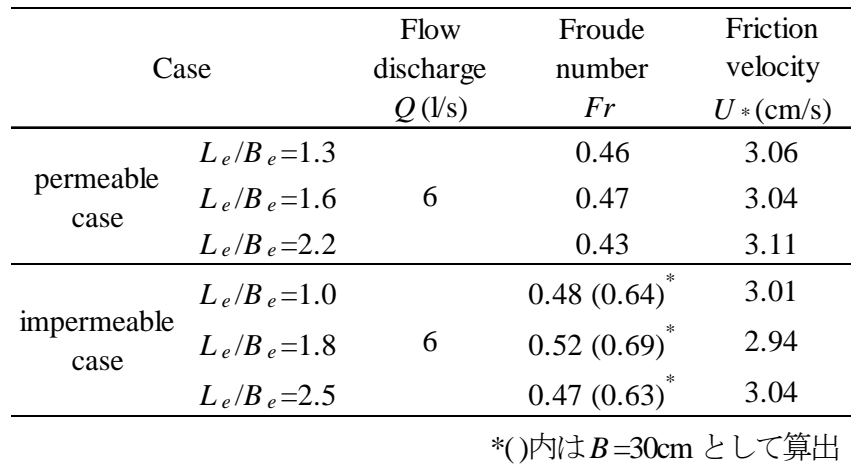

す.

流れの抵抗特性に関する実験条件は表-1 のように設定 した.いずれの条件においても非越流状態を対象としてい る. ここで, 時間平均水深は横断方向に顕著な差がみられ なかったため, 水深の計測位置は水路中央とし, 水深が流 下方向にほとんど変化しない領域において, 流下方向に平 均した水深の值を採択した．図-2 に著者ら ${ }^{12)}$ の研究によ り明らかとなった凹部のアスペクト比の変化に伴う水深 変化を示寸. 水深は植生および庶断物高さにより無次元化 している. これにより，凹部のアスペクト比を変化させる と流れの抵抗特性が大きく変化することが認められた. こ のことから, 四部のアスペクト比が変化すると流れ構造や 運動量輸送特性が変化し, その変化が流れの抵抗特性に大 きな影響を及ぼしたと予想される，そこで，流量 $Q=6 \mathrm{l} / \mathrm{s}$ の下, 流れの抵抗が極大值を示したケース, 透過性の凹部 流れでは $L_{e} / B_{e}=1.3$ および 2.2, 不透過性の凹部流れでは $L_{e} B_{e}=1.0$ および 2.5 に関して, さらに，流れの抵抗が極小 值を示したケース, 透過性の回部流れでは $L_{e} / B_{e}=1.6$, 不透 過性の凹部流れでは $L_{e} B_{e}=1.8$ に関して流動機構の検討を 行う. 実験条件を表-2 に示寸。ここで，フルード数は水 路幅を $B=40 \mathrm{~cm}$ として算出し, 摩擦速度は $U_{*}=\sqrt{g H I}$ より 算出している.

流動機構の検討においては，PIV 法による流速の多点 同時計測を行った．PIV は光源に空冷式ダブルパルス YAG レーザー（出力 $25 \mathrm{mj}$ ）を用い，シート光の厚さ $1 \mathrm{~mm}$ ，パルス間隔 500 $\mathrm{\mu s}$ に設定し，水路右岸から左岸 に向かってレーザーを照射し，水路上方より画像を撮 影した. 流速のサンプリング周波数は $15 \mathrm{~Hz}$ ，トレーサ

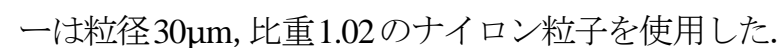



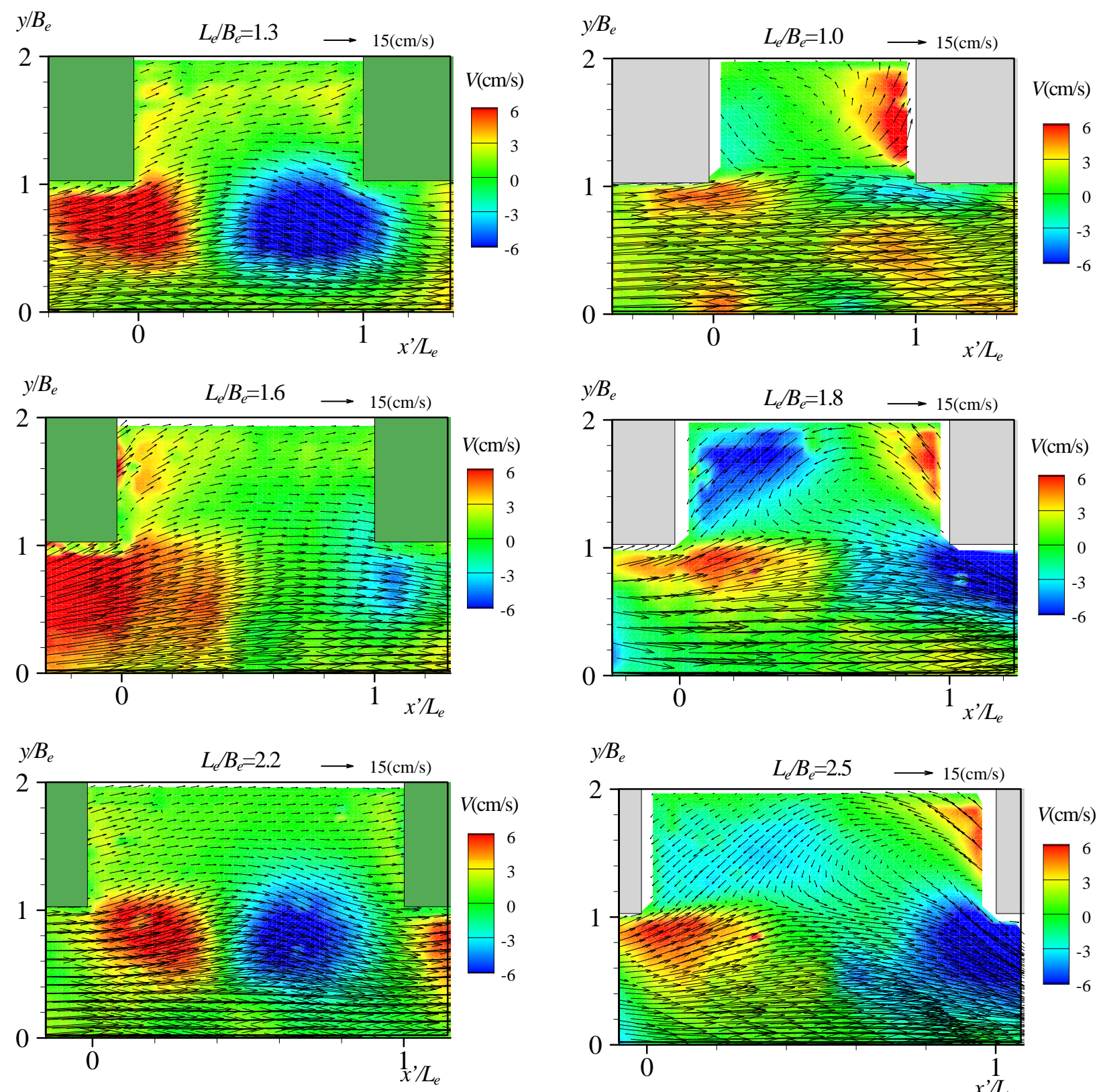

（a） 透過性（植生）

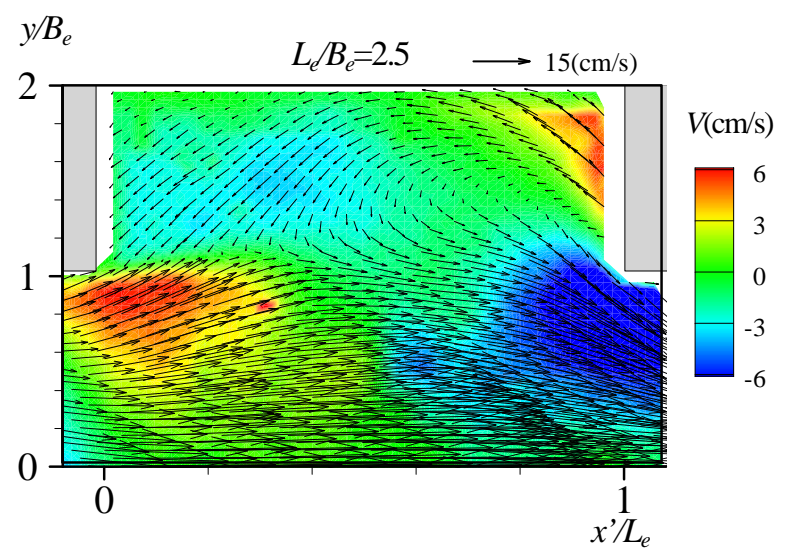

(b) 不透過性

図-3 時間平均流速ベクトル分布および横断方向流速 $V$ の等值線

PIV の計測対象領域は水平面 $x=300 \mathrm{~cm} \sim x=400 \mathrm{~cm}$ の範 囲内であり，計測領域の几部上流端を $x^{\prime}=0$ と設定した. 鉛直位置は藤田ら ${ }^{8)}$, 冨永ら ${ }^{13}$ の研究結果より, 本実験 条件のように凹部の奥行きが比較的大きい状態では流れ が二次元的となること，および著者らの実験によっても 同様な結果を得たため, 本論では半水深にて計測した結 果を用いた. 1 計測面での画像データは 2,000 枚（1,000 組のサンプル），計測時間は66.7s であった.

本論では口部の流下方向長さを凹部長さと呼び，さら に流下方向において，横断方向に植生帯および庶断物を 有する領域を植生域（vegetation area）または遮断物域 (blocker area)，植生帯および遮断物を有さない領域を 凹部域（cavity area）と呼ぶことにする.

\section{3. 時間平均流速分布}

各ケースにおける時間平均流速ベクトル分布および横 断方向流速 $V$ の等值線を図-3 に示寸．まず，透過性の凹 部流れについてみてみると,いずれのケースにおいても凹 部内では流向は流下方向を示しており，凹部上流域では凹 部に流入, 凹部下流では口部から流出する流れが形成され ている. $L_{e} B_{e}=2.2$ においては部の流下方向長さが長いこ とからその他のケースと比べ水交換が活発となる様子が 伺える.また，水深が極大值をとった $L_{e} / B_{e}=1.3$ および $L_{e} B_{e}=2.2$ では口部開口部周辺において流れが強く蛇行す る様子が同えるが，水深が極小值をとった $L_{e} B_{e}=1.6$ にお いてはその蛇行がその他のケースに比べ弱い様子が横断 

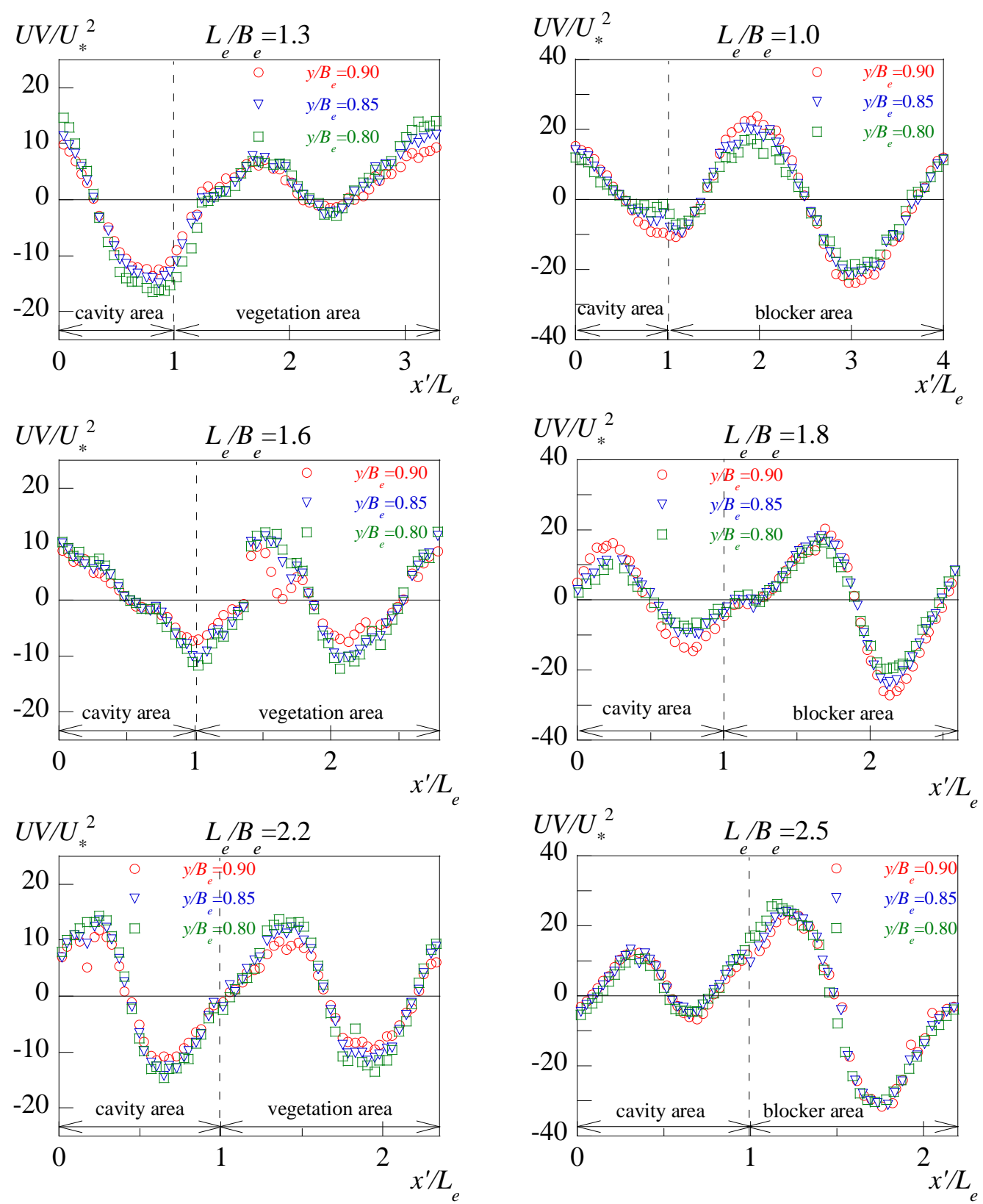

（a） 透過性（植生）

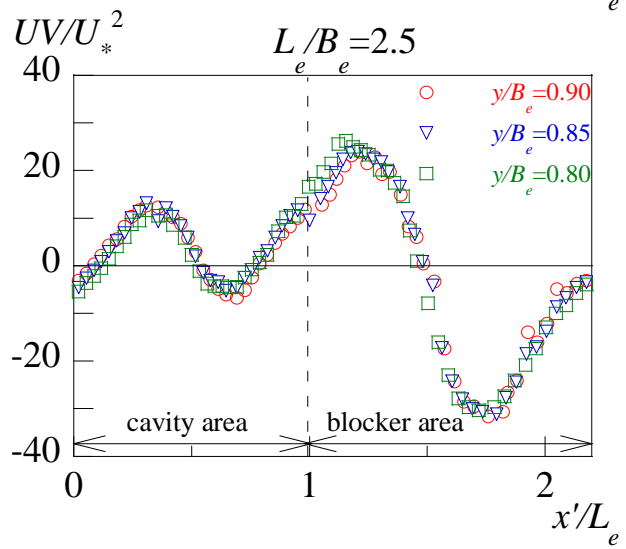

（b）不透過性

図-4 移流による運動量輸送UV の流下方向分布

方向流速の等值線からも読みとれる. このため, 水深が極 大值を示寸ケースにおいては水路全体の流れが大きく蛇 行することで流れの抵抗を大きくすることが示唆される.

不透過性の凹部流孔に注目寸る ${ }^{10)}$ と, 回部開口部におい ては透過性の凹部流孔と同様, いずれのケースにおいても 凹部上流域で凹部に流入, 凹部下流域では四部から流出す る流れが確認できる. 透過性の凹部流れとは異なり，遮断 物が流れを許容しないために $L_{e} B_{e}=1.0$ では四部中央を中 心とした循環流が凹部形状と同等のスケールで明瞭に形 成されている. $L_{e} / B_{e}=1.8$ および 2.5 においては $L_{e} / B_{e}=1.0$ ほ ど顕著ではないが凹部下流側を中心とした循環流が見ら れ, その横断方向スケールは回部幅程度, 流下方向にはそ れ以上のスケールで存在している.このように, 透過性お よび不透過性では特に凹部内において流れが顕著に異な ることが確認された。

\section{4. 運動量輸送特性}

水路内における側岸凹部の影響により，主流部と凹部お よひ林直生帯, 遮断物境界において運動量・物質の交換が促 進されることが予測される.ここで, 横断方向の運動量輸 送を次式で与える.

$$
\overline{u v}=\overline{\left(U+u^{\prime}\right)\left(V+v^{\prime}\right)}=U V+\overline{u^{\prime} v^{\prime}}
$$

$U V$ は移流による運動量輸送を， $\overline{u^{\prime} v^{\prime}}$ は流速変動による 運動量輸送を示す．各ケースの主流部と凹部およひ稙生

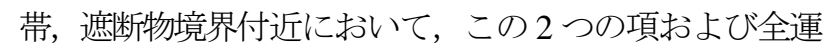
動量輸送について検討寸る. 

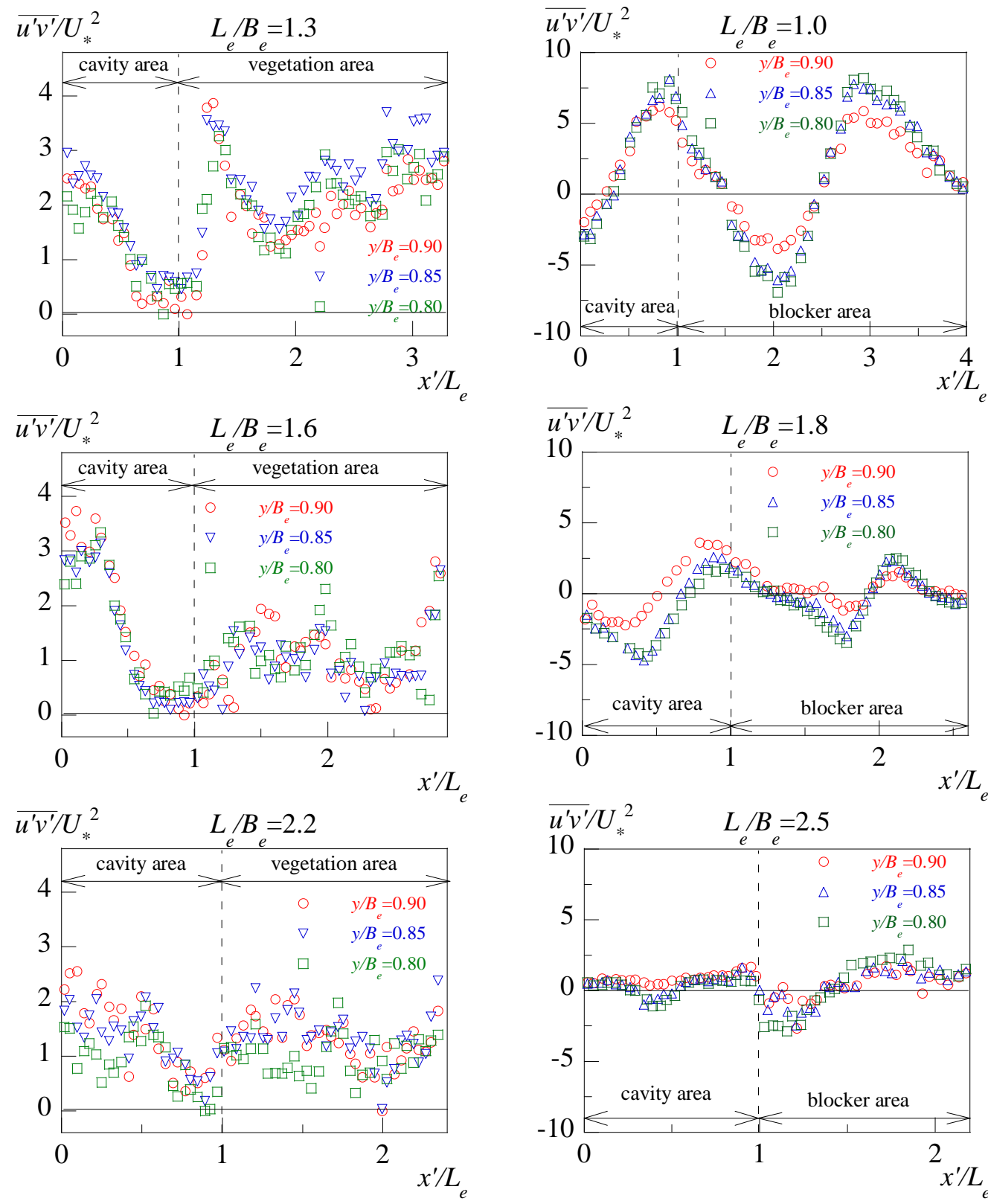

（a） 透過性（植生）

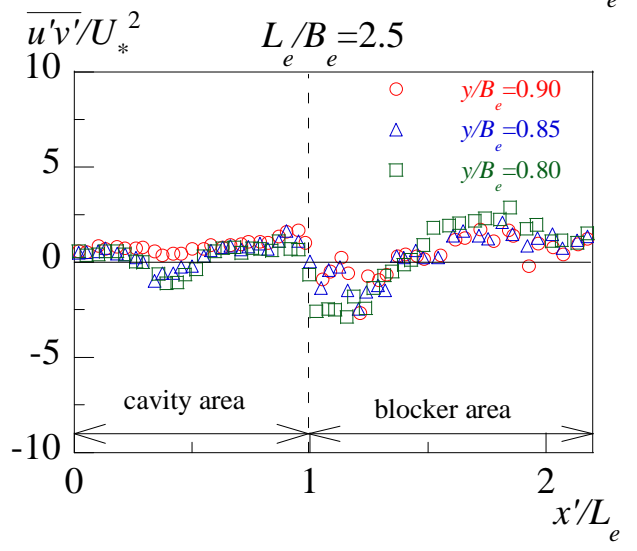

（b）不透過性

図-5 流速变動による運動量輸送 $\overline{u^{\prime} v^{\prime}}$ の流下方向分布

\section{1 移流による運動量輸送}

透過性および不透過性の凹部流れにおいて, 主流部と凹 部およひ植生帯, 遮断物との境界付近における移流による 運動量輸送 $U V$ を図-4に示寸。

透過性の凹部流孔において，凹部域に注目寸ると，凹部 上流側ではいずれのケースにおいても運動量は主流部か ら凹部内に運ばれており，凹部下流側では凹部内から主流 部に運動量が輸送されている様子が伺える. 図-3 の横断 方向流速成分 $V$ の空間分布より, $L_{e} / B_{e}=1.3$ および 1.6 では 凹部域の上流端および下流端近傍で凹部への流入および 流出速度がピーク值を示すことから，それらのケースでは 凹部上下流端にて運動量輸送量もピーク值を示すことが 認められる. 植生域については, $L_{e} / B_{e}=1.3$ ではほとんどの 領域で主流部から植生帯内に運動量が輸送されているが, 凹部アスペクト比が大きくなるにつれ, 植生帯中央付近に
て植生帯内から主流部一運動量が運び出される傾向が強 まる様子が見てとれる.このように, 流れの抵抗特性が最 も大きくなった $L_{e} B_{e}=2.2$ では, 運動量の交換が流下方向 に規則的に行われていることが認められた.この規則的交 換は部の流下方向長さが植生の流下方向長さに近い状 態にて発生寸ると考えられるとともに, 透過性であるため 植生の流下方向長さより凹部の流下方向長さが短い状態 で規則的交換が発生したものと推測される.

不透過性の凹部流れに関しても透過性の凹部流孔と類 似の挙動を示すものの, 四部域に比一゙遮断物域において移 流による運動量輸送量は大きな值を示した。これは，凹部 内が滞留域のような状態となるため, 凹部と主流部との水 交換が透過性ほど活発とならないこと，また，凹部域に比 べ遮断域では主流速が大きな值を示すことで移流による 運動量交換量が大きくなることなどが要因として挙げら 
れる. また, $L_{e} B_{e}=1.0$ に比べ 2.5 では流下方向において運 動量の交換が短い間隔で行われており, 運動量の受け渡し が活発となることが明らかとなった.

\section{2 流速変動による運動量輸送}

図-5 に主流部と凹部および植生帯，遮断物との境界付 近における流速変動による運動量輸送 $\overline{u^{\prime} v^{\prime}}$ の流下方向分 布を示す。

透過性の凹部流れにおいては, いずれのケースにおいて も凹部域, 植生域ともに流速変動による運動量輸送はほぼ 正の值を示し, 運動量は主流部から凹部および稙生帯内に 運び込まれている. 凹部域に関してはいずれも凹部下流域 に比べ部上流域の值が卓越している. これは凹部上流に 比べ部下流では横断方向の主流速差が小さくなるため だと考えられる. 植生域に関しては, 凹部のアスペクト比 が小さい $L_{e} / B_{e}=1.3$ において, その他のケースに比べ運動 量輸送量が流下方向に大きな值をとる傾向が見られる. $L_{e} / B_{e}=1.6$ および2.2では植生域において運動量輸送量が $x^{\prime}$ $L_{e}=1.03$ 程度の位置で極值をとり, そこから植生域上流側 および下流側に向かうにつれて值が減少していく.このよ うな傾向から，四部のアスペクト比が大きい状態に比べ, 狭い状態において流速変動による運動量輸送は活発に行 われていることが示唆される.

不透過性の凹部流れに注目寸ると, 透過性の凹部流孔と は異なり流速変動による運動量輸送量が正と負の值を規 則的に交互にとる様子が伺える. しかしながらその極值は 透過性に比へ比較的大きな值を示している. これは透過性 に比べ不透過性の凹部流れでは遮断物が流れを許容しな いことから横断方向の流速差が顕著となるためだと推察 される. 叫部域については植生域とは異なり, 凹部下流端 周辺にて運動量輸送量が極大值をとる. これについても不 透過性の凹部流れにおいては透過性に比べ部内外にお ける流速差が大きくなることが要因として考えられると ともに, 遮断物の影響で乱れが強く発生するためだと推測 される. また，透過性の凹部流れ同様，凹部のアスペクト 比が大きくなると運動量輸送量が小さな值を示すことが 認められる. このように, 各ケースにおいて流速変動によ る運動量輸送分布が異なる形態をとる要因として, せん断 不安定に起因する大規模渦の挙動の違いによる影響など が考えられるため, 今後各ケースの大規模渦の挙動や流速 変動の波形などに関して解析を進める必要がある.

ここで, いずれのケースにおいても流速変動による運動 量輸送量の絶対值は, 移流によるものと比べ小さな值を示 していることが確認できる.これにより本実験条件におい て, 流下方向に吅部を有する植生流孔では, 流速変動によ る運動量輸送に比べ, 移流による運動量輸送が卓越するこ とが明らかになった。

\section{3 全運動量輸送}

図-6に主流部と凹部および植生帯, 遮断物との境界付

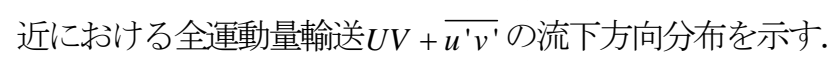

透過性および不透過性のいずれのケースにおいても, 流 速変動による運動量輸送に比べ移流による運動量輸送が 支配的となることから, 全運動量輸送は移流による運動量 輸送と類似の分布を示寸，その中で，不透過性の凹部流孔 においては透過性に比べ流速変動による運動量輸送の影 響を受けている様子が見てとれる.

透過性の凹部流孔についてみてみると, 水深が最大值を とった $L_{e} B_{e}=2.2$ では流下方向に規則的に運動量交換がな されており, 運動量輸送量の極值はその他のケースに比心 大きくなることが見てとれる. 不透過性においても運動量 輸送量の極值は $L_{e} B_{e}=2.5$ において大きな值を示している. これにより，四部およひ稙生帯と主流部との境界付近にお いて全運動量輸送量が大きくなるようなケースにおいて, 流れの抵抗が大きくなることが明らかになった. また，各 運動量輸送特性について確認したところ, 流下方向に植生 帯および遮断物が連なった状態から水深が最大值をとっ たケースまでロ部のアスペクト比を大きくしていくと， 流速変動による運動量輸送量は減少していき, 移流による 運動量輸送量は増大していくことが示唆された. その影響 により全運動量輸送量の形態が変化し, 流れの抵抗の大小 関倸に変化が生じると考えられる.

\section{5. 質量および運動量交換率}

主流部と側岸凹部および植生帯, 遮断物との境界におけ る質量交換率と運動量交換率について検討を行う。この境 界における質量交換率 $\phi$ および連動量交換率 $\theta$ を木村ら

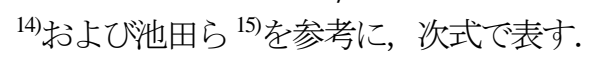

$$
\begin{aligned}
\phi & =\frac{1}{2 \rho U_{m} L} \int_{0}^{L} \rho|v| d x \\
& =\frac{1}{\rho U_{m} L} \int_{+} \rho v d x=\frac{1}{\rho U_{m} L} \int_{-} \rho v d x \\
\theta & =\frac{1}{\rho U_{m}{ }^{2} L} \int_{0}^{L} \rho \overline{u v} d x
\end{aligned}
$$

ここに, $L=L_{e}+L_{v}, \int_{+}, \int_{-}$は境界面上の横断方向流速が正 または負の領域で積分することを示す.

図-7 に $y / B_{e}=0.90$ における質量交換率, 図-8 に $y / B_{e}=0.90$ および 0.80 における運動量交換率と側岸口部のアスペク 卜比の関係を示す.

質量交換率に関しては, 透過性および不透過性の凹部流 れのいずれも部のアスペクト比が大きくなるにつれ質 量交換率も大きくなるという, 禰津ら ${ }^{7}$, 池田ら ${ }^{15)}$ およ び著者ら ${ }^{10)} の$ 研究結果と同様の傾向を示した. また, 質量 交換率は透過性に比べ不透過性において大きな值を示寸 ものの, 顕著な違いは見られなかった.

運動量交換率については, 透過性の凹部流れは不透過性 の凹部流れに比べ全体的に運動量交換率は大きな值を示 しており,このために透過性の凹部流れでは不透過性の凹 部流れに比べ流れの抵抗が大きくなると考えられる. 

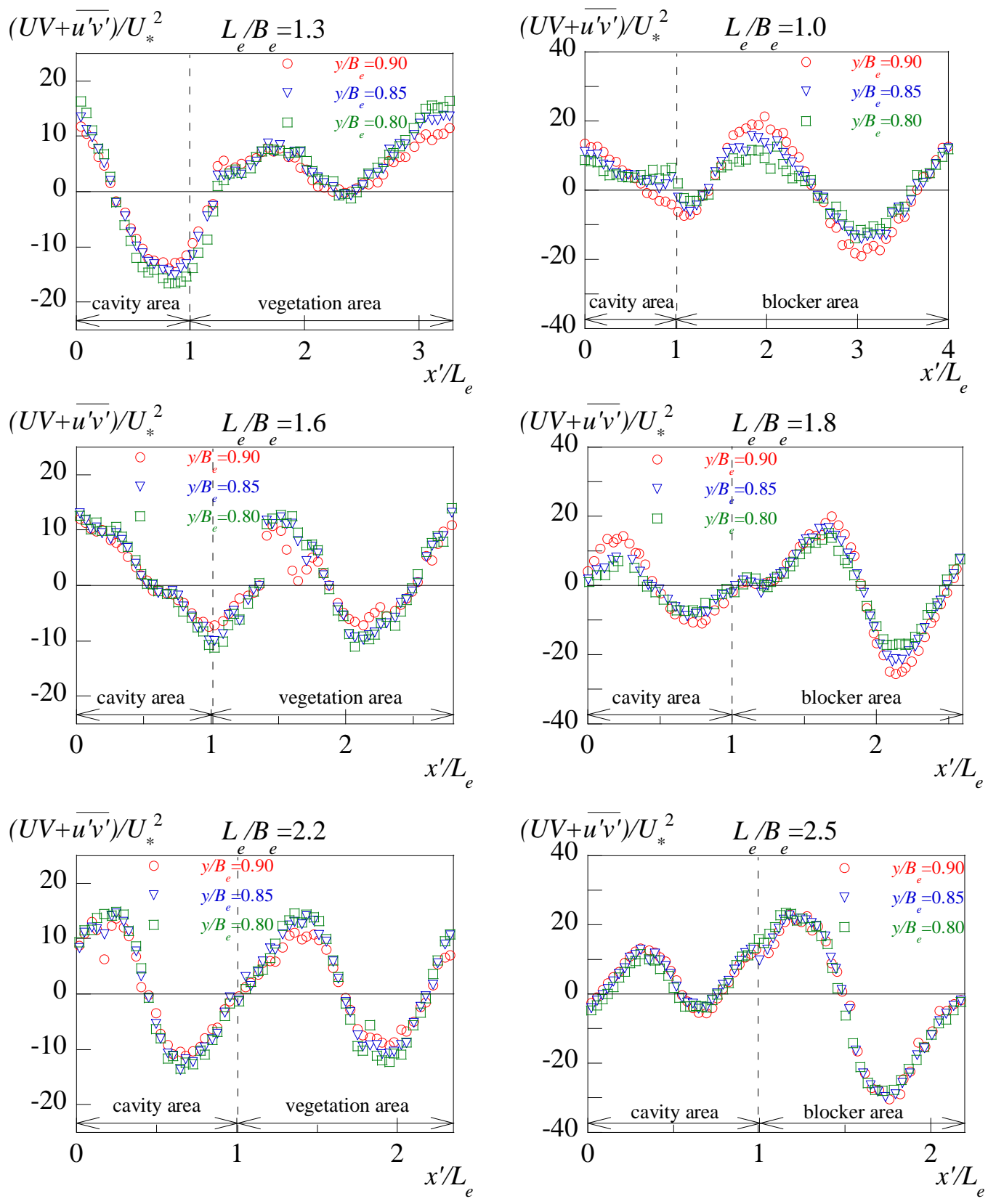

（a）透過性（植生）

（b）不透過性

図-6 全運動量輸送 $U V+\overline{u^{\prime} v^{\prime}}$ の流下方向分布

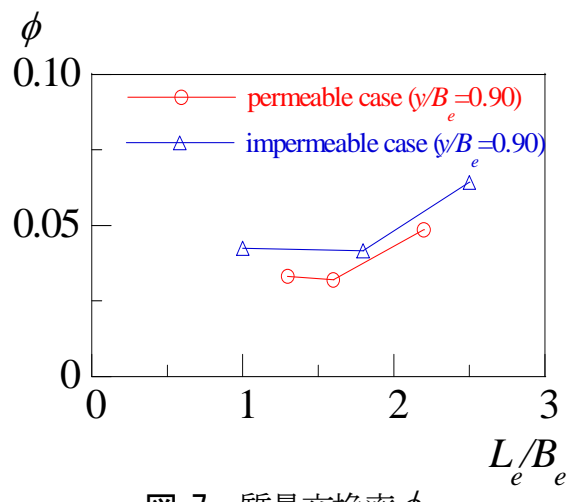

図-7 質量交換率 $\phi$

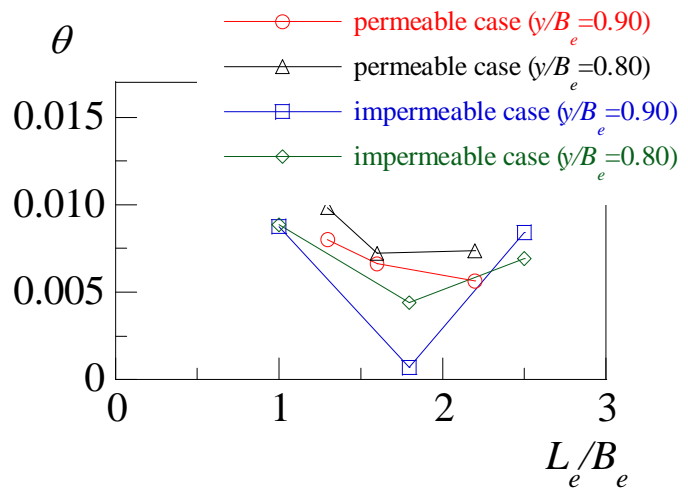

図-8 運動量交換率 $\theta$ 
$y / B_{e}=0.90$ に注目寸ると, 不透過性の口部流れでは水深が極 大值を示した $L_{e} B_{e}=1.0$ および 2.5 では, 水深が極小值を示 した $L_{e} / B_{e}=1.8$ と比べ運動量交換率は大きな值を示してい る. このため, 主流部と凹部および遮断物の境界における 運動量交換率が大きくなると, 流れの抵抗も大きくなるこ とが認められた．しかしながら，透過性の凹部流れにおい ては水深が極大值を示した $L_{e} B_{e}=2.5$ において，極小值を 示した $L_{e} / B_{e}=1.6$ よりも運動量交換率は小さな值を示した. そこで, $y / B_{e}=0.8$ における運動量交換率に関しても検討を 試みる. 検討寸る位置を変化させると, 水深が極大值を示 した $L_{e} / B_{e}=2.5$ の運動量交換率が $L_{e} B_{e}=1.6$ に比べ大きくな ることが認められた. これにより，流れの抵抗特性との大 小関係を考える上では, 運動量交換率をどの位置で評価す るかを考慮する必要があることが示唆された. また, 水深 方向も含めた水路全体における運動量輸送特性関しても 今後検討する必要がある.

\section{6. おわりに}

本研究では流下方向に連続的に透過性および不透過性 の側岸凹部を有する流れにおいて, 凹部アスペクト比の違 いが平均流特性や運動量輸送特性といった流動機構に与 える影響について検討した. 今後は水面変動特性や大規模 渦の挙動などについて検討していく必要がある. 得られた 知見は次のとおりである.

1) 半水深における水平面の時間平均流速ベクトルに注目 すると，透過性および不透過性のいずれのケースについ ても，主流部と凹部境界付近では凹部のアスペクト比の 違いによらず，凹部上流付近で凹部内に流入，凹部下流 付近で口部から流出寸る流れが確認された. しかしなが ら，その流出入量は吅部アスペクト比により変化するこ とが認められた。

2) 運動量輸送特性に注目寸ると, 凹部のアスペクト比が 大きくなるにつれ流速変動による運動量輸送量は減 少していき, 移流による運動量輸送量は増大していく傾 向か認められた. また, いずれのケースにおいても流速 変動に比べ, 移流による運動量輸送が支配的であること が明らかとなり，そのため全運動量輸送は移流による運 動量輸送と類似の分布傾向となることが認められた.

3) 質量交換率について検討した結果，いずれのケース も吅部のアスペクト比が大きくなるにつれ質量交換 率も増加することが認められた，また，運動量交換率 では, 透過性の几部流孔は不透過性に比べ全体的に大き な值を示し，これにより透過性の凹部流れでは不透過性 の凹部流れに比べ流れの抵抗が大きくなることが明ら かになった. さらに, 不透過性の凹部流孔においては境 界付近において流れの抵抗と運動量交換率の大小関係 がほぼ一致したものの, 透過性においてはその境界の設 定位置により大小関係が異なる結果となった. これによ り，流れの抵抗特性との大小関係を考える上では，運動 量交換率をどの位置で評価するかを考慮する必要があ
るとともに, 水深方向も含めた水路全体における運動量 輸送特性に関しても検討する必要があることが示唆さ れた.

\section{参考文献}

1) F. G. Carollo, V. Ferro and D. Termini : Flow Resistance Law in Channels with Flexible Submerged Vegetation, Journal of Hydraulic Engineering, Vol.131, No.7, pp.554-564, 2005.

2) Juha Järvelä : Effect of submerged flexible vegetation on flow structure and resistance, Journal of Hydrology 307, pp.233-241, 2005.

3) 冨永晃宏, 長尾正志, 劉建, 鈴木徹也 : 洪水流の抵 抗と流れ構造に及ぼす高水敷樹木群配置の影響, 水 工学論文集, 第 39 巻, pp.477-482, 1995.

4) 中矢哲郎, 池田駿介, 戸田祐嗣 : 側岸部植生密度の 変化が開水路横断方向運動量輸送に及ぼす影響, 河 川技術論文集，第 9 巻，pp.383-388，2003.

5) 関根正人, 浦塚健史 : 側岸部に交互に繁茂する植生 群落によって生成される流れと河床形状について, 水工学論文集, 第 44 巻, pp.813-818, 2000.

6) 田中貴幸, 大本照憲, 田中寿幸 : 流下方向に不連続的 植生群落を有する開水路流孔の抵抗特性と運動量輸送, 水工学論文集, 第 52 巻, pp.763-768, 2008.

7) 禰津家久, 鬼束幸樹, 池谷和哉, 高橋俊介: わんど形 状が河川に及ぼす影響に関する水理学的研究，応用力 学論文集, Vol.3, pp.813-820, 2000.

8) 門谷健, 藤田一郎, 椿涼太 : 開水路側岸口部のアスペ クト比の違いが三次元流孔構造に及ぼす影響, 応用力 学論文集, Vol.11, pp.881-888, 2008.

9) Uijttewaal, W.S.J., D. Lehmann, A.van Mazijk : Exchange processes between a river and its groyne fields: Model experiments, J.H.E, ASCE, 1273(11), pp.928-936, 2001.

10）田中貴幸, 大本照憲 : 流下方向に連続的に側岸凹部を 有寸る開水路流れの抵抗特性と流動機構, 水工学論文 集, 第 53 巻, pp.889-894, 2009.

11) 禰津家久, 矢野勝士, 光成洋二 : 浸透性を有するワ ンド流れ周辺の物質交換特性に関する可視化実験, 水工学論文集, 第 48 巻, pp.541-546, 2004.

12）田中貴幸，大本照憲 : 透過性および不透過性の側岸凹 部流れにおける抵抗特性と流動機構, 土木学会論文集 B1 (水工学)，Vol.68, No.4, pp.I_805-I_810, 2012.

13）冨永晃宏, 谷川幸男, 久田陽史 : 人工わんどの水交換 機構とその制御法に関する研究，水工学論文集，第 46 巻, pp.571-576, 2002.

14) 木村一郎, 細田尚, 安永良, 村本嘉雄 : 開水路流れ死 水域周辺の水面変動・流体混合特性, 水工学論文集, 第 41 巻, pp.711-716, 1997.

15）池田駿介, 吉池智明, 杉本高 : 不透過水制群を有寸る 流孔の構造に関寸る実験的研究，水工学論文集，第 43 巻, pp.281-286, 1999.

(2013 年 3 月 18 日 受付) 